\title{
THOUGHTS ON OGIVE FORMATION
}

\author{
By Henry W. Posamentier \\ (Department of Geosciences, Rider College, ${ }_{2083}$ Lawrenceville Road, Lawrenceville, New Jersey o8648, \\ U.S.A.)
}

\begin{abstract}
The formation of ogives is examined from a structural point of view. It is suggested that the dark bands represent large-crystal, bubble-free ice which was transported from near the glacier base up toward the glacier surface by the processes of folding and/or reverse faulting due to compressive flow at the base of an ice fall, while the white bands represent relatively small-crystal, bubble-rich near-surface ice. The variation in compression to account for periodic folding and/or reverse faulting is explained by seasonal variation in flow velocity through an ice fall.

Résumé. Idées sur la formation des ogives. La formation des ogives est examinée d'un point de vue structural. On suggère que les bandes sombres représentent des gros cristaux sans inclusions de bulles d'air, de glace qui a été transportée depuis les régions proches de la base du glacier jusqu'a la surface par le processus du plissement et/ou de failles de renversement dues à l'écoulement compressif à la base d'une chute de séracs, tandis que les bandes claires représentent des cristaux relativement petits riches en bulles de glace de surface. Les variations de compression dont il faut tenir compte pour expliquer la périodicité des plissements et/ou des failles de renversement sont expliquées par des variations saisonnières de la vitesse d'écoulement dans une chute de séracs.

Zusammenfassung. Uberlegungen zur Bildung von Ogiven. Die Bildung von Ogiven wird von einem strukturellen Standpunkt aus betrachtet. Es wird angenommen, dass die dunklen Bänder aus grosskörnigem, blasenfreiem Eis bestehen, das aus der Umgebung des Gletscheruntergrundes zur Gletscheroberfläche durch Faltungs- und/oder Rückfaltungsprozesse unter dem Druckfliessen an der Basis eines Eisfalles transportiert wurde, während sich die weissen Bänder aus relativ feinkörnigem, blasenreichem, oberflächennahem Eis zusammensetzen. Die Druckschwankungen die zu periodischen Faltungs- und/oder Rückfaltungsvorgängen führen, werden aus den jahreszeitlichen Schwankungen der Fliessgeschwindigkeit in einem Eisfall erklärt.
\end{abstract}

OGrves may be defined as transverse bands of alternating white and dark ice, convex down-glacier, emanating from the bases of ice falls on temperate glaciers. Several explanations have been suggested to account for this phenomenon (King and Lewis, 196I; Fisher, I962). This study does not attempt to refute these theories but merely suggests alternative processes which could play a role in ogive formation.

King and Lewis (196r) suggest that the dark bands below an ice fall represent the glacier ice which descended the ice fall during summer. During this period ablation is maximum and accumulation minimum. Dirt and dust transported onto the glacier surface from nearby ice- and snow-free slopes, coupled with high ablation rate, result in surficial glacier ice which is characteristically comprised of mainly bubble-free, large ice crystals with high dirt content. In contrast, during winter when ablation is low and accumulation high and nearby slopes are mantled by fresh snow, ice crystals in glacier ice descending an ice fall are typically small with many bubble inclusions and little dirt content; thus forming the so-called white band. As King and Lewis (I96I) correctly observe, these alternating bands may become accentuated down-glacier by differences in albedo between dark and light bands and concurrent accumulation of washed-in dirt in the resultant troughs.

The present study views this phenomenon from a structural glaciological point of view. It should be re-emphasized here that the writer does not disagree with the views put forth by King and Lewis (I96I) but wishes to suggest a possible contemporaneous process. The velocity of glacier ice through an ice fall is greater than either immediately up-glacier or down-glacier, and, because discharge remains constant through this stretch, an increase in velocity must be associated with a decrease in cross-sectional area of the glacier through the ice fall. The shear stresses associated with the extending flow here are thought to initiate foliation parallel to the bedrock floor (Ragan, 1969). At the base of the ice fall an abrupt drop in valley gradient results in decreased velocity accompanied by compressive flow. Compression here results in folding and faulting of the folia (Ragan, 1969; Miller, unpublished). Folia attitudes below the Vaughan Lewis ice fall on the Juneau Icefield, Alaska, have been examined in detail by Miller (unpublished). He observes that most folia seem to dip down-glacier in the up-glacier sector of a white band and up-glacier in the down-glacier sector. While a wide range of dips is observed, "the highest percentages, however, center around $70^{\circ}$ dip on each limb" of the white band. In addition Miller (unpublished) notes that the strike of these folia seems to parallel the form of the ogive. Ragan (1969) in mapping below ice falls observes that most folia seem to dip up-glacier. 


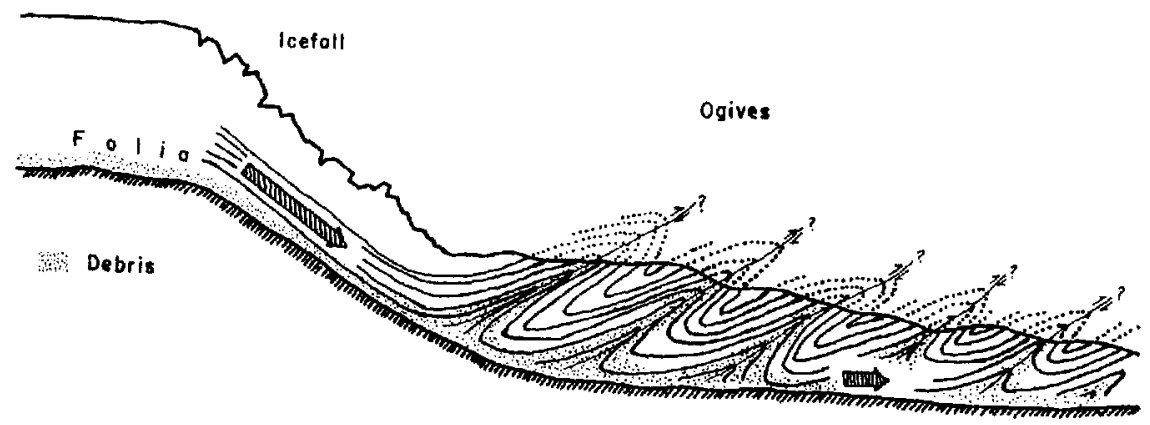

Fig. I. Ogive formation according to folding with possible reverse faulting model.

Two possible interpretations are shown in Figures $\mathrm{I}$ and 2. Both interpretations are based largely on an assumption that the dark bands are not simply superficially dirt-covered as King and Lewis (1961) suggest. They noted that when a patch on a dark band which was cleared and swept of all dirt it appeared as white as the adjacent white band and that after one year again had become much dirtier than this white band. They conclude then that the dirt in the area of the dark band was "extremely sparse in the body of the glacier". There is, however, an alternative explanation. It would be enlightening to observe whether the cleared patch of dark band would have been as white as a cleared patch of white band. At this point on the glacier, some $800 \mathrm{~m}$ down-glacier from the ice fall, ablation should have resulted in a greater concentration of dirt on white bands than on similar white bands further up-glacier; thus a dark band swept clean might well be as white as a relatively dirty white band. The dirtying process on the dark band would then quickly reclaim the cleared patch by the processes of ablation and redistribution of dirt by supraglacial melt-water streams. Nevertheless, if the dark bands should prove to be truly dirt-free at depth the blue bubble-free nature of this ice could still indicate deep-glacier origins for this ice. The models illustrated in Figures $\mathrm{x}$ and 2 would then have to be slightly altered to indicate that basal dirt does not reach the glacier surface though the mechanism of folding and/or faulting could still occur.

Figure $\mathrm{I}$ illustrates generalized isoclinal folding below an ice fall, as suggested by Ragan's (1969) data. This folding may or may not be associated with axial plane reverse faulting. Miller's (unpublished) data would indicate symmetrical rather than isoclinal folds and again with possible axial plane faulting. Such tight folding could well bring those folia which were formerly in close proximity to the bedrock floor, high up through the glacier. Axial plane faulting would further enhance this situation. These folia with their dirt-rich ice may then be exposed by subsequent ablation. The light-colored, bubbly nature of the white bands, on the other hand, is typical of ice which had stayed close to the glacier surface at all times. Due to differential ablation the result is thus a classic case of inversion of topography with synclinal ridges and anticlinal troughs as ablation proceeds slowly on the high-albedo white bands and more rapidly on the low-albedo dark bands.

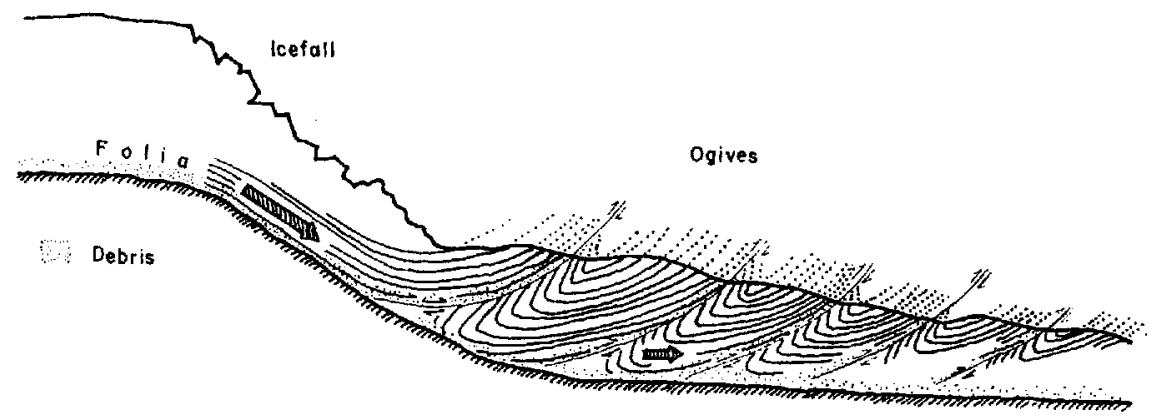

Fig. 2. Ogive formation according to reverse faulting with associated drag folding model. 
Figure 2 illustrates a possible alternative structural explanation. Here rather than folding being the predominate mechanism, reverse faulting with associated drag folding is emphasized. Again the folia attitude shown is that conforming generally to Ragan's (1969) observations. It would not be difficult, however, to illustrate the same mechanism so that it would conform to Miller's (unpublished) observations. Here, reverse faulting due to compression at the base of an ice fall is responsible for lifting dirt-rich, bottom-most tectonic folia toward the glacier surface. Again, these dirty zones become the dark bands and subsequent troughs down-glacier from the ice fall. Even if the dirt-rich folia should not reach the surface, these zones would still be comprised of ice typically bubble-free and follow the same mechanism as outlined above.

The seeming annual nature of ogives can be explained readily to be compatible with either of the aforementioned models. Because data regarding seasonal fluctuation of glacier velocity through an ice fall unfortunately is sparse and inconclusive, until further data become available the following is suggested as a reasonable tentative hypothesis. It is suggested here that a decrease in glacier velocity through an ice fall in winter and an increase in summer could account for the annual formation of ogives. In summer months increased amounts of water acting as an englacial and sub-glacial lubricant could result in a velocity increase over this steep stretch where basal slip is of such importance to glacier flow, while during winter months a decrease in supraglacial, englacial, and subglacial melt water through this attenuated stretch of the glacier could result in a velocity decrease. Increased summer velocity would result in increased compression at the ice fall base with corresponding reverse faulting and/or anticlinal folding in this area. Lower winter velocity, on the other hand would result in decreased compression here with corresponding synclinal folding and/or absence of reverse faulting.

Much detailed field work, including structural mapping, year-round surveying, and bore-hole deformation studies are of course essential in order to confirm or reject these suggested models. Nevertheless, it is hoped that these models will stimulate further examination of this unique glacial phenomenon.

The author is greatly indebted to M. M. Miller for affording the opportunity to participate in the Juneau Icefield Research Program for 197 r and for many invaluable stimulating discussions in the field.

MS. received zo November 1976 and in revised form 7 January 1977

\section{REFERENCES}

Fisher, J. E. 1962. Ogives of the Forbes type on Alpine glaciers and a study of their origins. Fournal of Glaciology, Vol. 4 , No. 3I, p. $53-6$ I.

King, G. A. M., and Lewis, W. V. rg6r. A tentative theory of ogive formation. Fournal of Glaciology, Vol. 3 ,

No. 29, p. $913-39$.
Miller, L. R. Unpublished. Englacial structures of the Vaughan Lewis icefall, and related observations on the Juneau Icefield, Alaska, 1967-1969. [M.Sc. thesis, Michigan State University, 1970.]

Ragan, D. M. I969. Structures at the base of an ice fall. Fournal of Geology, Vol. 77, No. 6, p. 647-67. 